\title{
HOLOCENE INSET FILLS OF THE ODRA RIVER IN THE RACIBÓRZ BASIN
}

\author{
Krzysztof J. WÓjcicki, PrZemyseaw ŚleszyŃski, SŁawomir Mazur \\ University of Silesia, Faculty of Earth Sciences, Sosnowiec, Poland
}

Manuscript received December 20, 2009

Revised version August 1, 2010

\begin{abstract}
Wójcicki K.J., ŚleszyÝsKi P. \& MAZur S., 2010. Holocene inset fills of the Odra River in the Racibórz Basin. Quaestiones Geographicae 29(3), Poznań 2010 pp. 85-93, 5 Figs., 1 Tab. ISBN 978-83-62662-04-3. ISSN 0137-477X. DOI: 10.2478/v10117-010-0025-2.
\end{abstract}

АвSTRACT. Geomorphic and lithological research conducted in the Odra River valley between Koźle and Krapkowice led to recognition of the postglacial development of the upper Odra River valley floor, for the first time, on the basis of a larger number of absolute datings. The formation of the inset alluvial fills by a meandering river started during the Early Holocene at the latest; however, the absence of a clearly developed system of large Late Vistulian palaeomeanders is notable within the analysed reach of the valley. Mid- and Late Holocene alluvial series were deposited by a river that exhibited a tendency to decrease in channel sizes. Nevertheless, large meanders were formed again in historical times. Oxbow fills in the Odra River valley are dominated by mineralogenic deposits. Their sedimentation can be correlated with the accretion of overbank and colluvial sheets in the valley floor. In the light of radiocarbon chronology, a relationship between Neolithic and subsequent phases of settlement in the catchment and the intensive deposition of these sediments cannot be ruled out.

KEYWORDS: valley evolution, fluvial processes, alluviation, palaeochannels, Odra River

Krzysztof J. Wójcicki, Przemystaw Śleszyński, Stawomir Mazur, Department of Quaternary Palaeogeography and Palaeoecology, Faculty of Earth Sciences, University of Silesia, Będzińska 60, 41-200 Sosnowiec, Poland, e-mail:krzysztof.wojcicki@us.edu.pl

\section{Introduction}

Issues related to the structure and evolution of the upper Odra River valley require further research. The works performed to date have focused on the analysis of the extent and age of river terraces. During the interwar period, Assmann (1934) distinguished a system of five river terraces in the vicinity of Opole. In his opinion, the alluvial terrace of the modern valley floor was formed during the Holocene. In the early
Holocene, the low Pleistocene terrace was covered by fine-grained alluvium. According to Walczakówna and Baranowska (1964), a system of six terraces can be observed in the vicinity of Krapkowice. They distinguished lower (1-2 m above the river level) and upper (2-3 $\mathrm{m}$ above the river level) terraces within the Holocene floodplain. The higher terrace $(4-5 \mathrm{~m}$ above the river level) the cited authors considered as Pleistocene. The idea that the latter terrace was formed in the younger part of the Vistulian was 


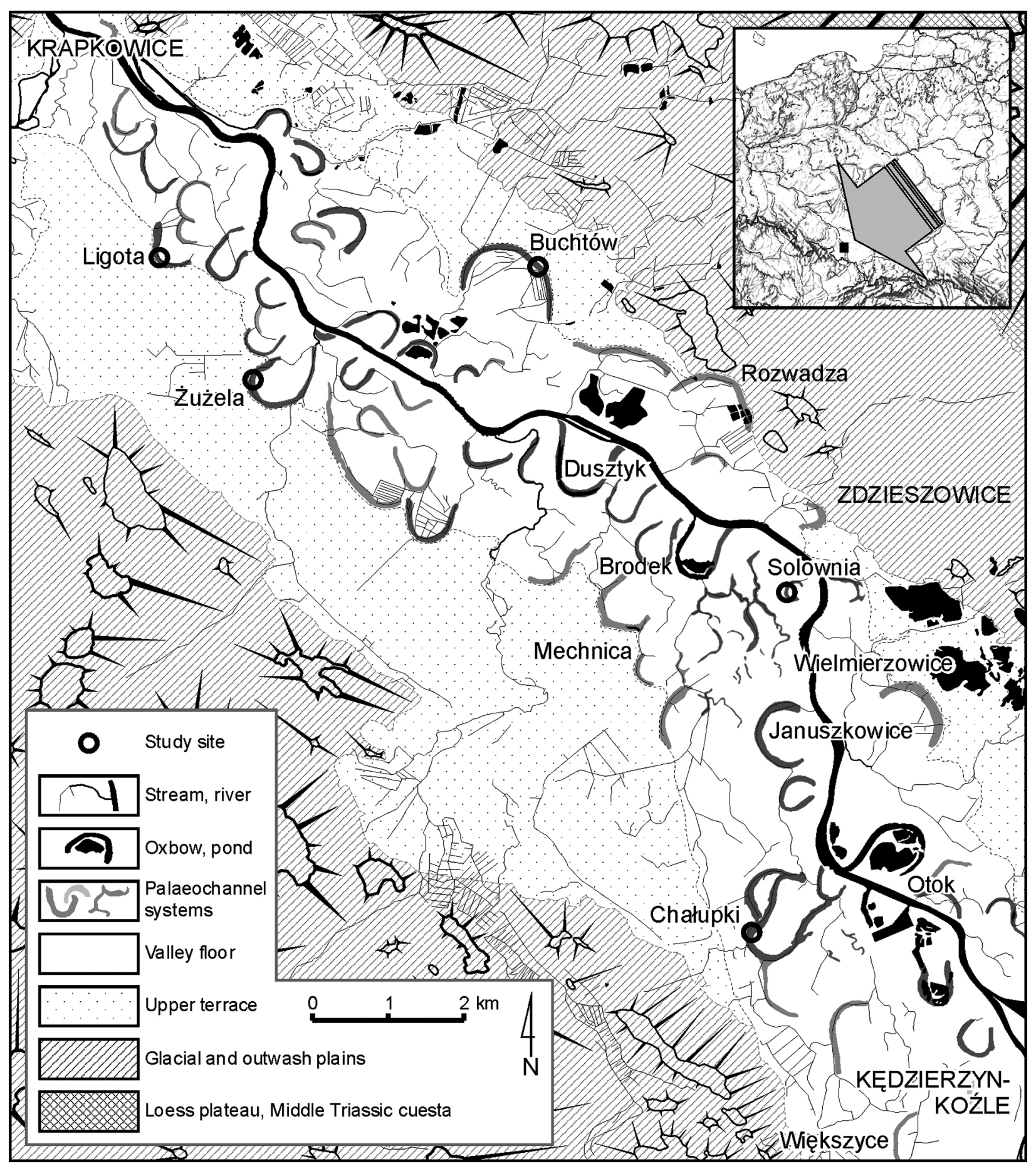

Fig. 1. Geomorphological map of the Odra River valley between Kędzierzyn-Koźle and Krapkowice

challenged by Szczepankiewicz (1974) on the basis of studies conducted between Racibórz and Brzeg. According to him, three of the five terraces distinguished were formed in the Holocene. The two youngest terraces, which date to $<2.7$ ka ${ }^{14} \mathrm{C} \mathrm{BP}$ and the last century respectively, are covered by "industrial mada" in the vicinity of Racibórz. The sandy gravelly terrace III, cov- ered by Late Holocene "agricultural mada", was dated to the Post-Atlantic period based on the "black oaks" present. Waga (1994) moved the origins of terrace III to the Late Vistulian-Early Holocene transition. A weakness of the Odra River valley development schemes mentioned above is the absence (scarcity) of absolute datings that would confirm the stratigraphic pat- 
terns assumed. The aim of the present paper is to describe the system of inset alluvial fills and outline the history of postglacial development of the upper Odra River valley floor, for the first time, on the basis of an analysis of the Odra River palaeochannel pattern and a larger number of radiocarbon datings.

\section{Study area}

The research conducted focused on the valley reach between Koźle and Krapkowice. In this reach, the Odra River channel is regulated and its average gradient amounts to $0.38 \mathrm{mkm}^{-1}$. The width of the valley within the reach analysed ranges from 5.4 to $6.3 \mathrm{~km}$. Along valley sides, fragments of a sandy Pleistocene terrace elevated from 6 to $8 \mathrm{~m}$ above the river level have been preserved. The width of the Holocene valley floor ranges from $4 \mathrm{~km}$ in the vicinity of Koźle to $1.5 \mathrm{~km}$ upstream of Krapkowice. On average, the floodplain surface is elevated from 2 to $4 \mathrm{~m}$ above the river level. Owing to the morphology of the valley floor, terrace systems within the reach analysed cannot be distinguished in more detail. Altitude differences within the valley floor generally do not exceed $2 \mathrm{~m}$. They are related to palaeomeander systems and accompanying point bars. Only in the vicinity of Mechnica has a multiple channel system been preserved. Within the alluvial plain, mainly sand, sand with gravel and river mud are exposed (Trzepla 1997). Biogenic deposits are present locally. The largest peatland (63 ha), which is situated in Większyce, was studied already in the 1920s (Schubert 1930). Contemporary research (Mazur 2006) has shown that the sequence of peat and gyttja is over $4 \mathrm{~m}$ thick locally. The accumulation of biogenic deposits was initiated not later than in the early Holocene (a date of $9370 \pm 150{ }^{14} \mathrm{C} \mathrm{BP}$ was obtained from a sample at a depth of 3.64-3.69 m). Thus it may be concluded that during the Pre-Boreal period the floor of the Odra River valley lay at a level similar to the present one. During the Sub-Atlantic period, the development of the fen at Większyce was affected by increasing anthropogenic pressure. At the foot of a valley slope, peat dated to $1210 \pm 60$ ${ }^{14} \mathrm{C}$ BP (the sample at a depth of 0.45-0.52 m) was covered by sandy colluvium.

\section{Results}

Within the Holocene valley floor, Odra River palaeomeanders can be distinctly observed. The Buchtów site, which is located at the foot of the Pleistocene terrace (Fig. 2), is among the largest palaeomeanders (radius of curvature $\mathrm{Rm} \approx 600$ $\mathrm{m}$, channel width $\mathrm{w}_{\mathrm{bkf}} \approx 70 \mathrm{~m}$ ). This is the only well-preserved form of this size in the analysed reach of the valley. In the vicinity of Rozwadza, a slightly smaller palaeomeander $(\mathrm{Rm} \approx 560 \mathrm{~m})$ can be found. Morphological surface at the Buchtów site rises about $3 \mathrm{~m}$ above the mean Odra River stage. Within the core analysed, the top of gravelly sand, interpreted as channel deposits, was found at a depth of $2.55 \mathrm{~m}$. First, the oxbow was filled by mud interbedded with thin sand and fine gravel beds. These sediments were penetrated by Phragmites australis rootlets, which were dated to $8930 \pm 100{ }^{14} \mathrm{C} B P$ at a depth of $2.47-2.55 \mathrm{~m}$. Organic-rich deposits; initially dominated by remains of reed were accumulated above. The lower layer of these deposits was dated to $9790 \pm 90{ }^{14} \mathrm{C} \mathrm{BP}$ at a depth of 1.30-1.35 m. Beginning at a depth of $0.75 \mathrm{~m}$, dispersed sand grains appear in the peat. The uppermost layer of this sequence is organicrich sand and gravel whose thickness increases toward the slope.

Other relatively large palaeomeanders $(\mathrm{Rm} \approx 410-445 \mathrm{~m})$ create a meander loop in the neighbourhood of Wielmierzowice and Januszkowice. A well-preserved form in Januszkowice $\left(\mathrm{Rm} \approx 410 \mathrm{~m}, \mathrm{w}_{\text {bkf }} \approx 60 \mathrm{~m}\right.$ ) is situated close to the present river channel. Morphological surface at the site rises by less than $1 \mathrm{~m}$ above the mean Odra River stage. Until now, no organic matter has been obtained at the lower part of the fill sequence and dating of the oxbow formation using the radiocarbon method was not available. The series of sediments infilling the palaeochannel consists primarily of homogeneous overbank deposits. Within the cross-section analysed, the thickness of these fine-grained $(\mathrm{Mz}=6.31-8.06$ phi) sediments is up to $1.2 \mathrm{~m}$ (Śleszyński 2006). The uppermost segment of the fill consists of a 0.2 $\mathrm{m}$ layer of biogenic deposits dominated by Cyperaceae rootlets and Phragmites australis epidermis.

There is a much more numerous group of palaeomeanders with a radius of curvature ranging from 235 to $340 \mathrm{~m}$. These palaeomeanders are 

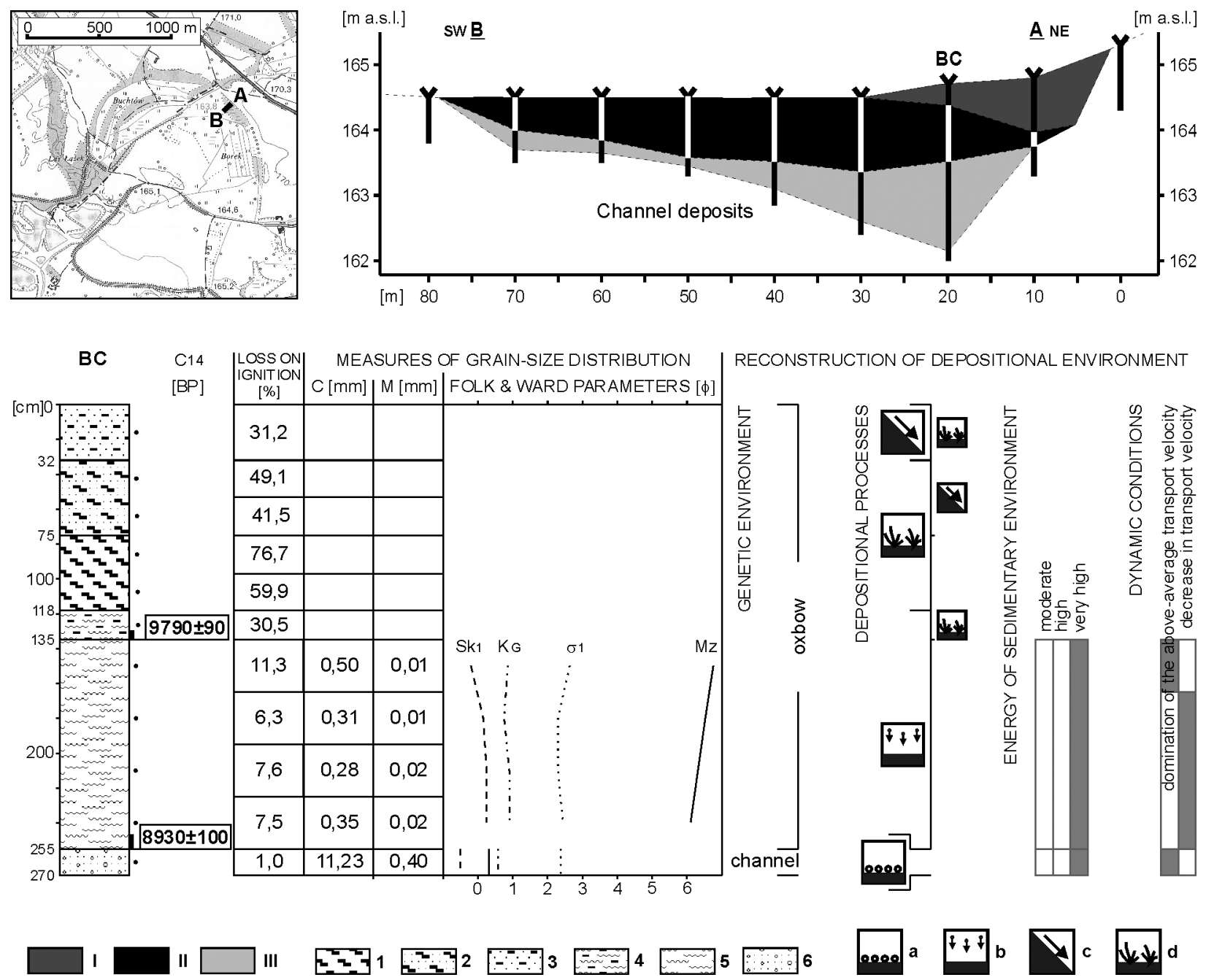

Fig. 2. The Buchtów site. Lithology and stratigraphy of deposits and reconstruction of depositional environment: Palaeochannel fill: I - sandy colluvium with organic matter, II - organic deposits with sand and mud, III - fine-grained alluvium with organic matter

Core lithology: 1 - organic deposits, 2 - sandy organic deposits, 3 - organic-rich sand, 4 - organic-rich mud, 5 - mud, 6 - sand with gravel Depositional processes: $\mathrm{a}$ - deposition from rolling, $\mathrm{b}$ - deposition from uniform suspension, $\mathrm{c}$ - outwash deposition, $\mathrm{d}$ biogenic accumulation

located both at the foot of the Pleistocene terrace and within the floodplain. They are represented, among others, by the Chałupki, Ligota and Żużela sites. The Chałupki palaeomeander $\left(\mathrm{Rm} \approx 290 \mathrm{~m}, \mathrm{w}_{\mathrm{bkf}} \approx 70 \mathrm{~m}\right)$ is situated within the valley floor; $350 \mathrm{~m}$ away from the edge of the Pleistocene terrace (Fig. 3). Morphological surface at the site rises by $2 \mathrm{~m}$ above the mean Odra River stage. Within the Chałupki core, the top of fine and medium-grained sands was found at a depth of $2.3 \mathrm{~m}$. These were considered channel alluvium deposited in dead-water zones. Grey mud was deposited above, which include a small amount of organic remains beginning at a depth of 2.06 $\mathrm{m}$. Later, peat dominated by Phragmites australis and Cyperaceae remains dated to $7530 \pm 90{ }^{14} \mathrm{C} \mathrm{BP}$ at a depth of 1.76-1.82 m was accumulated. In the light of radiocarbon dating, peat accumulation was halted after $4130 \pm 90 \mathrm{BP}$ (the sample at a depth of 0.9-0.95 m). Above it, a layer of black sticky deposits with humic substance is present. Beginning at a depth of $0.72 \mathrm{~m}$, it gradually turns into brown "mada". Overbank deposits include brick fragments, which proves that the layer analysed was anthropogenically disturbed.

The palaeomeander in Ligota near Krapkowice $\left(\mathrm{Rm} \approx 285 \mathrm{~m}, \mathrm{w}_{\mathrm{bkf}} \approx 80 \mathrm{~m}\right)$ is situated at the foot of an almost $3 \mathrm{~m}$ high Pleistocene terrace (Fig. 4). Samples were collected about $1250 \mathrm{~m}$ away from the present Odra River channel. The top of sand layer considered channel sediments is present at a depth of $2.34 \mathrm{~m}$. Above it, a thin layer of grey mud can 

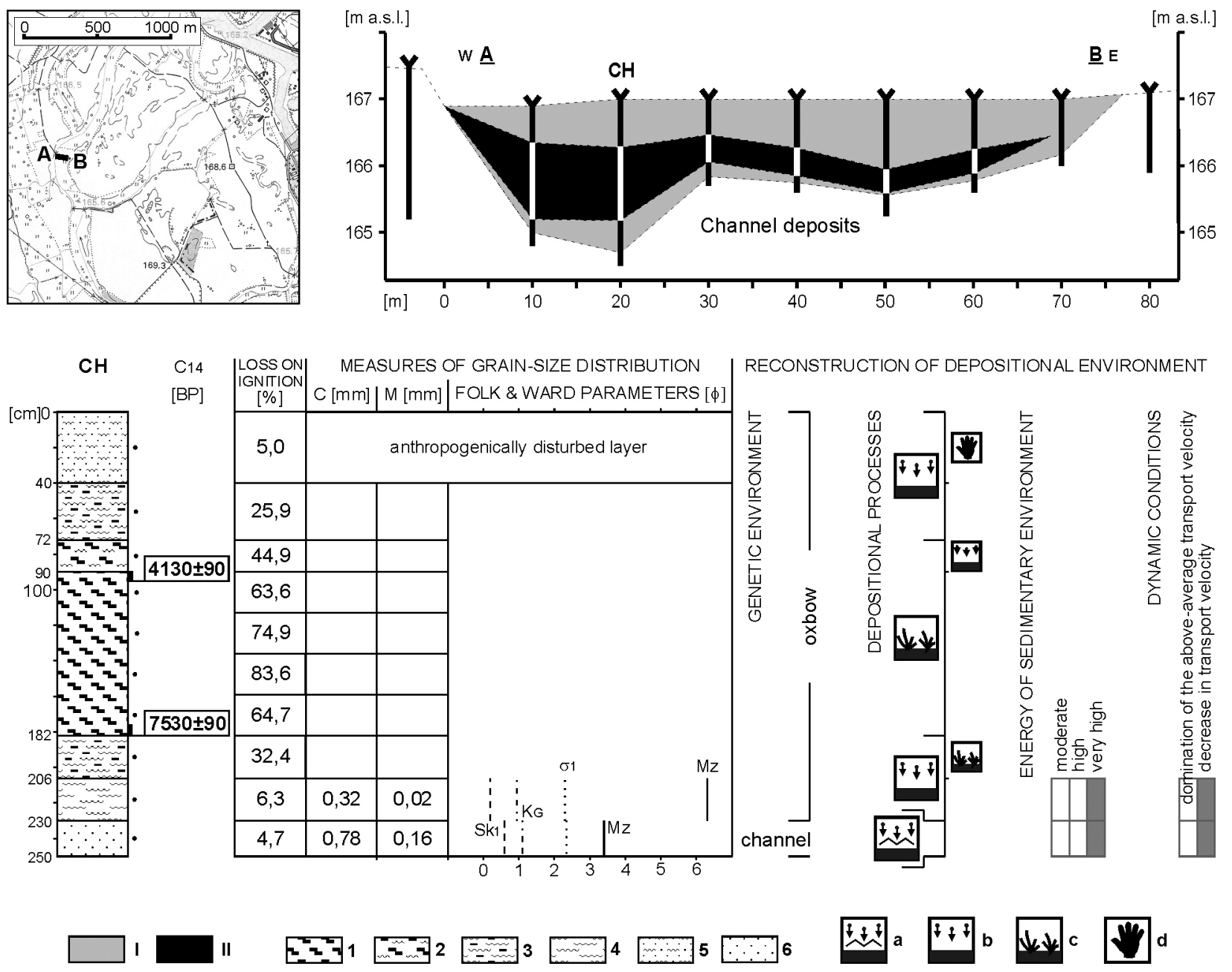

Fig. 3. The Chałupki site. Lithology and stratigraphy of deposits and reconstruction of depositional environment: Palaeochannel fill: I - fine-grained alluvium with organic matter, II - biogenic deposits, locally with mud

Core lithology: 1 - organic deposits, 2 - muddy organic deposits, 3 - organic-rich mud, 4 - mud, 5 - muddy sand, 6 - sand

Depositional processes: a - deposition from graded suspension, $\mathrm{b}$ - deposition from uniform suspension, $\mathrm{c}$ - biogenic accumulation, $\mathrm{d}$ anthropogenically disturbed sediments

be found, which turns into grey-brown mud with organic debris at a depth of $2.22 \mathrm{~m}$. Organic matter found at a depth of 2.16-2.24 m has been dated to $6420 \pm 80{ }^{14} \mathrm{C} \mathrm{BP}$. A series of muddy deposits with organic matter (loss on ignition up to $38.7 \%$ ) reaches to a depth of $0.84 \mathrm{~m}$. Alder peat was accumulated above; from the base $(0.8-0.84 \mathrm{~m})$ dated to $1270 \pm 50{ }^{14} \mathrm{C}$ BP and from the top $(0.36-0.42 \mathrm{~m})$ dated to $720 \pm 50{ }^{14} \mathrm{C} \mathrm{BP}$. The sediment sequence is topped by a layer of organic-rich sandy silt with gravels. According to the interpretation assumed, these sediments were deposited at the foot of the slope as a result of sheet wash or rill erosion.

The Żużela palaeomeander $(R \mathrm{~m} \approx 335 \mathrm{~m}$, $\mathrm{w}_{\mathrm{bkf}} \approx 72 \mathrm{~m}$ ) is situated at the foot of the Pleistocene terrace. Morphological surface at the site rises by around $1.5 \mathrm{~m}$ above the mean Odra River stage.
Within the Żużela core, the top of medium - and fine-grained sands $(\mathrm{Mz}=2.86 \mathrm{phi})$ was found at a depth of $2.61 \mathrm{~m}$. These were considered channel alluvium deposited in dead-water zones. The oxbow was infilled in conditions of large delivery of allochthonous deposits. The sediment sequence starts with a layer of grey sandy silt $(\mathrm{Mz}=4.58$ phi) containing some plant debris. Organic matter participation increases above (loss on ignition $20 \%$ ). At a depth of $2.33-2.37 \mathrm{~m}$, remains of aquatic plants and wood debris dated to $6340 \pm 80{ }^{14} \mathrm{C} \mathrm{BP}$ are present among others. The highest organic matter content was exhibited by the layer from a depth of $1.53-1.81 \mathrm{~m}$. A sample collected from its top (1.53-1.59 m) was dated to $5880 \pm 70{ }^{14} \mathrm{C}$ BP. Above, a complex of stratified silty-sandy deposits is present. The deposition of 

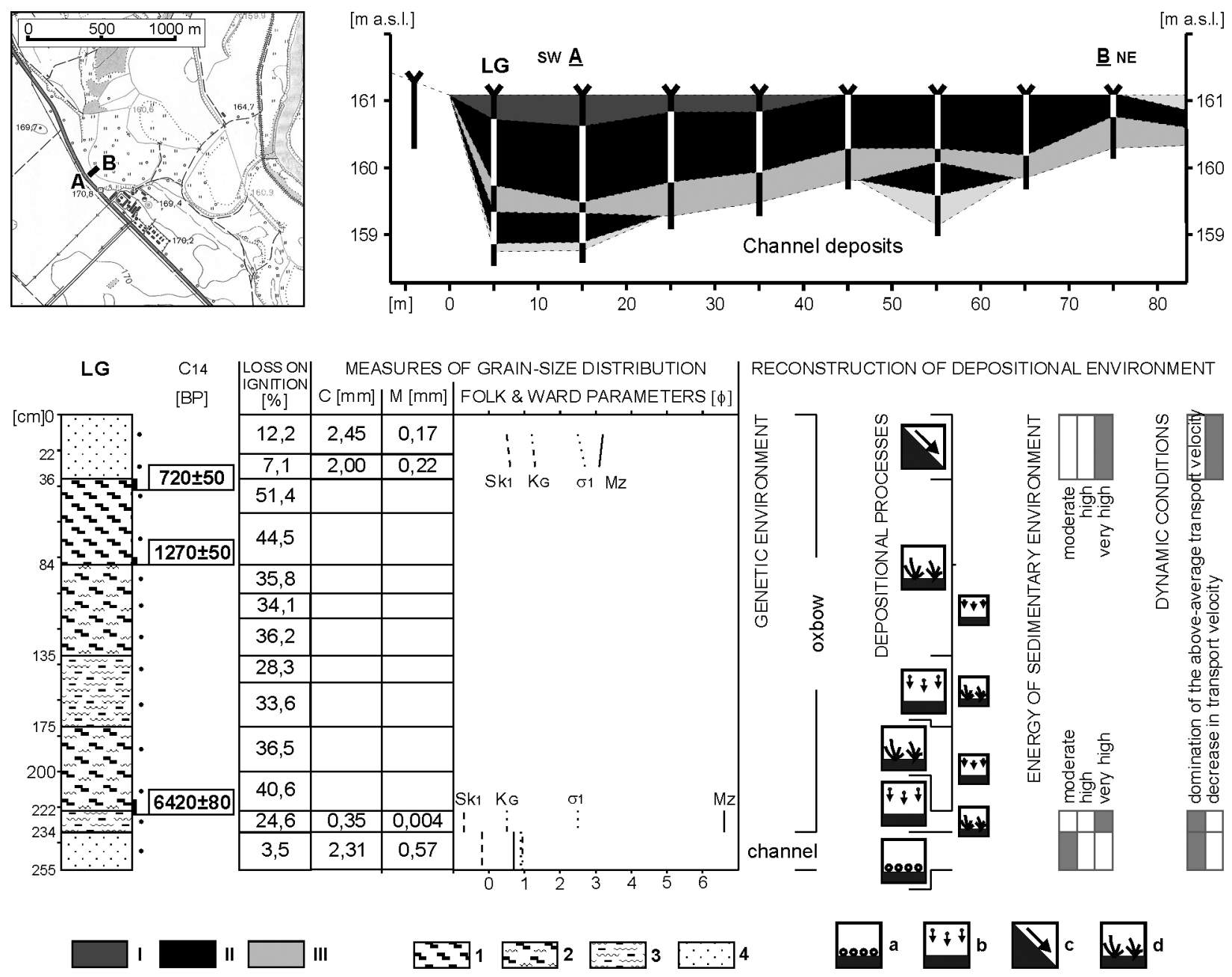

Fig. 4. The Ligota site. Lithology and stratigraphy of deposits and reconstruction of depositional environment: Palaeochannel fill: I - colluvial sand and muddy sand, II - organic deposits with sand and mud, III - alluvial mud and mud with organic matter

Core lithology: 1 - organic deposits, 2 - muddy organic deposits, 3 - organic-rich mud, 4 - sand

Depositional processes: $\mathrm{a}$ - deposition from rolling, $\mathrm{b}$ - deposition from uniform suspension, $\mathrm{c}-$ outwash deposition, $\mathrm{d}$ - biogenic accumulation

the uppermost segment of this series was related to the activity of slope processes.

Another group of palaeomeanders consists of very numerous and well-preserved, but smaller forms $\left(R m \approx 160-235 \mathrm{~m}, \mathrm{w}_{\text {bkf }} \approx 30-65 \mathrm{~m}\right)$ situated close to the present river channel. They are represented by the Solownia site $\left(\mathrm{Rm} \approx 165 \mathrm{~m}, \mathrm{w}_{\mathrm{bkf}} \approx 31\right.$ $\mathrm{m})$. Morphological surface at the site rises by less than $1 \mathrm{~m}$ above the mean Odra River stage. Samples were collected less than $450 \mathrm{~m}$ away from the river channel (Fig. 5). The Solownia palaeochannel is relatively narrow but deep. The top of sandy deposits considered channel alluvium is present at a depth of $3.84 \mathrm{~m}$. The palaeomeander is filled by fairly homogeneous grey mud interbedded with fine sand. These deposits do not contain autochthonous organic matter; wood debris is present instead. A wooden fragment from the Solownia core, which was embedded in finegrained flood sediments at a depth of 3.40-3.84 m, was dated to $1290 \pm 60{ }^{14} \mathrm{C} \mathrm{BP}$. The infill sequence is topped by a thin layer $(0.1 \mathrm{~m})$ of organic-rich sediments, which were accumulated in present times.

In the vicinity of Otok, Brodek and Dusztyk, young oxbows that were cut off as a result of Odra River regulation can be found. On archival maps (Urmesstischblatt 1825a; Urmesstischblatt $1825 b)$, these were still Odra River meanders. They are of considerable size $(\mathrm{Rm} \approx 300-350 \mathrm{~m}$, $\mathrm{w}_{\mathrm{bkf}} \approx 45-75 \mathrm{~m}$ ). 

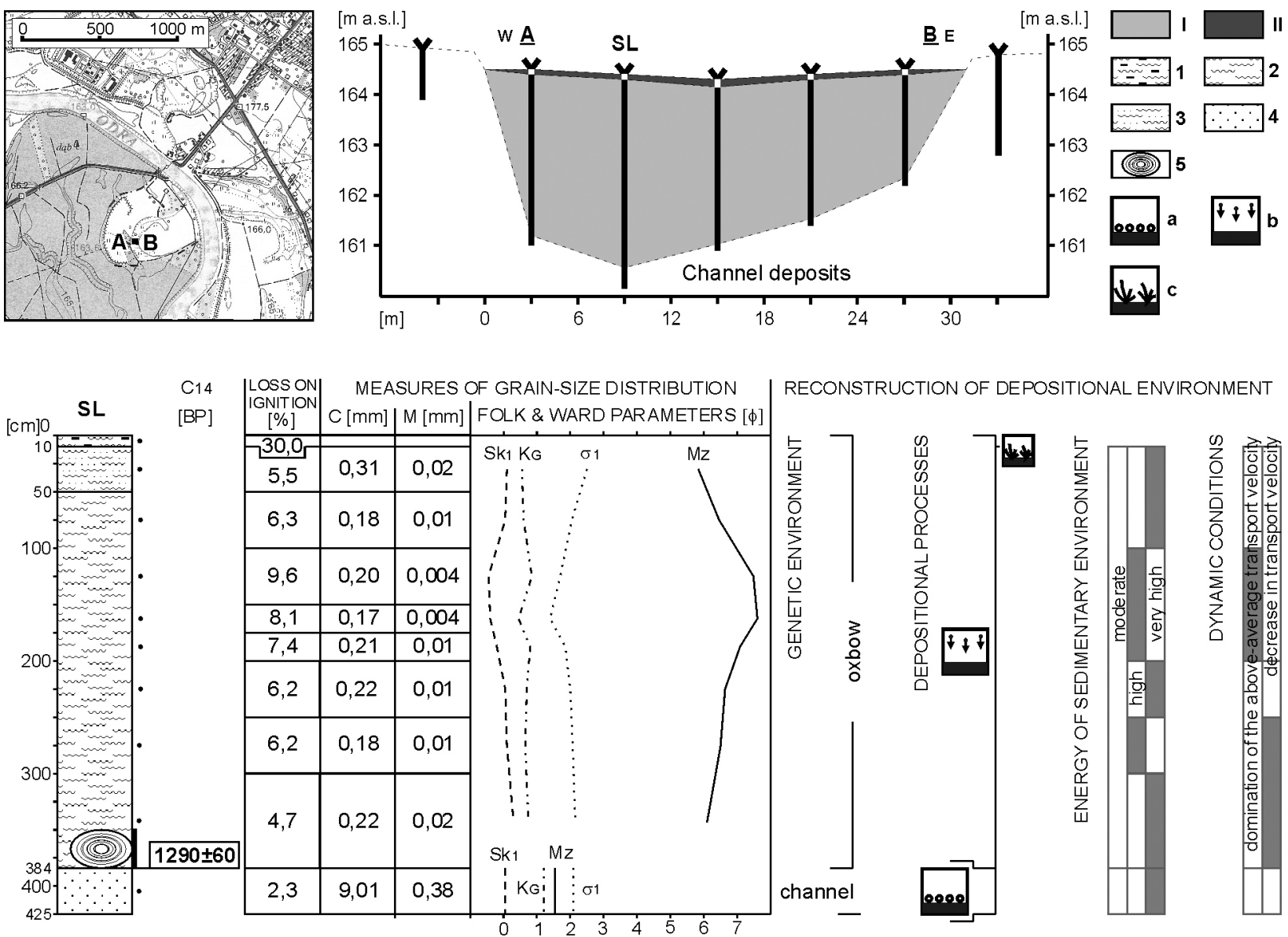

Fig. 5. The Solownia site. Lithology and stratigraphy of deposits and reconstruction of depositional environment:

Palaeochannel fill: I - fine-grained alluvium, II - fine-grained alluvium with organic matter

Core lithology: 1 - organic-rich mud, 2 - mud, 3 - sandy mud, 4 - sand, 5 - trunks and branches

Depositional processes: $\mathrm{a}$ - deposition from rolling, $\mathrm{b}$ - deposition from uniform suspension, $\mathrm{c}$ - biogenic accumulation

\section{Discussion}

An analysis of aerial photographs has revealed several inset fill systems within the upper Odra River valley floor, which were mainly produced by a meandering river (Table1). Initial conditions; namely the low gradient of the valley bottom and the sandy valley fill inherited from Pleistocene, probably created favourable conditions for the development of a sinuous river. However, in the light of research conducted to date, the Odra River channel pattern was transformed into a meandering one slightly later than it was the case with the neighbouring valleys of the Kłodnica and Osobłoga Rivers (Wójcicki 2006). Within the Odra River valley, there is no clearly developed system of large Lateglacial palaeomeanders. The radius of curvature of the largest Odra River palaeomeander at the Buchtów site is just under two to four times larger than Late Holocene forms.
In contrast, radiuses of curvature of the largest Lateglacial palaeomeanders within the Kłodnica River valley are four to twelve times larger than Late Holocene forms. The $\mathrm{w} / \mathrm{d}$ ratio of the Buchtów palaeomeander is about 10, which is less than half the value exhibited by Lateglacial palaeomeanders of the Kłodnica River (Wójcicki 2006). Additionally, the status of large palaeomeanders at Januszkowice and Wielmierzowice is unclear. It cannot be ruled out that these are relatively young forms. This is suggested by their location - slightly above the river level and close to its present channel. Despite these doubts, datings of palaeomeander fills and fen sediments at Większyce have supplied sufficient data to allow the revision of the Odra River valley development model put forward by Szczepankiewicz (1974). The idea according to which the processes of fluvial incision to the modern floodplain level occurred from the end of the Pleistocene until 
Table 1. Palaeochannels of the Odra River between Koźle and Krapkowice, Racibórz Basin

\begin{tabular}{|c|c|c|c|}
\hline Generation & $\begin{array}{l}\text { Geometrical } \\
\text { parameters }\end{array}$ & $\begin{array}{l}\text { Datings } \\
(14 C \text { BP) }\end{array}$ & Comments \\
\hline Oxbows & $\begin{array}{l}\mathrm{Rm} \approx 300-350 \mathrm{~m} \\
\mathrm{wbkf} \approx 45-75 \mathrm{~m}\end{array}$ & $\begin{array}{l}<200 \text { years (based } \\
\text { on archival maps) }\end{array}$ & $\begin{array}{c}\text { a few forms in the nearest neighbourhood of the mod- } \\
\text { ern channel; among others sites at Otok, Brodek and } \\
\text { Dusztyk }\end{array}$ \\
\hline $\begin{array}{l}\text { Small palaeome- } \\
\text { anders }\end{array}$ & $\begin{array}{l}\mathrm{Rm} \approx 160-235 \mathrm{~m} \\
\mathrm{wbkf} \approx 30-65 \mathrm{~m}\end{array}$ & $\geq 1290 \pm 60$ a) & $\begin{array}{l}\text { very numerous and well preserved forms in the neigh- } \\
\text { bourhood of the modern channel; among others a site } \\
\text { at Solownia }\end{array}$ \\
\hline $\begin{array}{l}\text { Medium palae- } \\
\text { omeanders }\end{array}$ & $\begin{array}{l}\mathrm{Rm} \approx 235-340 \mathrm{~m} \\
\mathrm{wbkf} \approx 55-75 \mathrm{~m}\end{array}$ & $\begin{array}{l}>7530 \pm 90 \mathrm{~b}) \\
>6420 \pm 80 \mathrm{c}) \\
>6340 \pm 80 \mathrm{~d})\end{array}$ & $\begin{array}{l}\text { numerous but varied preserved forms both at the foot } \\
\text { of the Pleistocene terrace and within the floodplain; } \\
\text { among others sites at Chałupki, Żużela and Ligota }\end{array}$ \\
\hline $\begin{array}{l}\text { Large palaeome- } \\
\text { anders }\end{array}$ & $\begin{array}{l}\mathrm{Rm} \approx 410-445 \mathrm{~m} \\
\mathrm{wbkf} \approx 60 \mathrm{~m} \mathrm{e})\end{array}$ & - & $\begin{array}{l}\text { varied preserved forms both at the foot of the Pleis- } \\
\text { tocene terrace at Wielmierzowice and within the flood- } \\
\text { plain at Januszkowice }\end{array}$ \\
\hline $\begin{array}{l}\text { The largest palae- } \\
\text { omeanders }\end{array}$ & $\begin{array}{l}\mathrm{Rm} \approx 560-600 \mathrm{~m} \\
\mathrm{wbkf} \approx 70 \mathrm{~m} \mathrm{f})\end{array}$ & $\begin{array}{l}>9790 \pm 90 \mathrm{f}) \\
>8930 \pm 100 \mathrm{f})\end{array}$ & $\begin{array}{l}\text { varied preserved forms at the foot of the Pleistocene } \\
\text { terrace at Buchtów and Rozwadza }\end{array}$ \\
\hline $\begin{array}{l}\text { Multiple palaeo- } \\
\text { channels }\end{array}$ & wbkf $\approx 20-30 \mathrm{~m}$ & - & $\begin{array}{c}\text { a few systems within the floodplain in the vicinity of } \\
\text { Mechnica }\end{array}$ \\
\hline
\end{tabular}

Data for sites: a) Solownia, b) Chałupki, c) Żużela, d) Ligota, e) Januszkowice, f) Buchtów

the Atlantic period should be rejected. The oldest inset fills in the valley floor started to form not later than during the early Holocene, while Szczepankiewicz (1974) assumed that they dated from the Atlantic period.

Palaeomeander fills of the Odra River is characterized by a high content of allochthonous sediments. Among these, mineralogenic fine-grained alluvium dominates. The latter could be deposited synchronously with a sheet of overbank deposits widespread on the valley floor (Assmann 1934; Jahn, Piasecki 1952; Szczepankiewicz 1974; Trzepla 1997). The original deposition of these sediments was probably related to the formation of oxbows immediately after they had been cut off. In the light of radiocarbon chronology, this stage can be dated to more than $9790 \pm 90 \mathrm{BP}$ at the Buchtów site, more than $7530 \pm 90 \mathrm{BP}$ at the Chałupki site, more than $6420 \pm 80 \mathrm{BP}$ at the Żużela site and more than $6340 \pm 80 \mathrm{BP}$ at the Ligota site. During the second oxbow development phase, a decrease in flood sediment supply was recorded at most sites. The accumulation of autochthonous sediments was continuously disturbed nevertheless. This is evidenced by the silting up of biogenic sediments in the Chałupki, Żużela and Ligota cores. At the latter site, a short period of undisturbed biogenic accumulation only started around $1270 \pm 50{ }^{14} \mathrm{C}$ BP. In upper parts of the cores analysed, mineralogenic sediments appear again; these are related to the intensification of fluvial processes or the activation of slope proc- esses. According to datings, biogenic accumulation was finally halted not more than $5880 \pm 70$ ${ }^{14} \mathrm{C}$ BP in the Żużela core, $4130 \pm 90{ }^{14} \mathrm{C}$ BP in the Chałupki core, $720 \pm 50{ }^{14} \mathrm{C}$ BP in the Ligota core and $1210 \pm 60{ }^{14} \mathrm{C} \mathrm{BP}$ at the edges of the Większyce fen. The two first dates indicate that a significant increase in mechanical denudation in the Odra River basin could have occurred as early as the Neolithic period. According to Kulczycka-Leciejewiczowa (1993), activities of farming societies of the Danubian Culture and particularly the Funnel Beaker Culture, could have led to the creation of open landscapes on the Głubczyce Plateau as early as the mid $4^{\text {th }}$ millennium BC. Thus it cannot be ruled out that "agricultural mada" started to form earlier than $2700{ }^{14} \mathrm{C} \mathrm{BP}$, as Szczepankiewicz (1974) claims. Based on the high rate of sedimentation in the Solownia core, it may however be assumed that sedimentation processes on the Odra River floodplain culminated in the last millennium.

\section{Conclusions}

The relief of the Odra River valley floor between Koźle and Krapkowice is primarily the result of meandering river activity. The formation of the inset alluvial fills by the meandering river started during the Early Holocene at the latest; however, the absence of a clearly developed system of large Late Vistulian palaeomeanders 
is notable within the analysed reach of the valley. Mid- and Late Holocene alluvial series were deposited by a river that exhibited a tendency to decrease in channel sizes. Nevertheless, large meanders were formed again in historical times.

The bankfull stage elevation estimated for the Odra River palaeomeanders ranges from around $3 \mathrm{~m}$ (the oldest forms) to less than $1 \mathrm{~m}$ (Sub-Atlantic forms) above modern river level. This indicates a stable, albeit relatively minor tendency to channel incision occurred throughout the Holocene.

Oxbow fills in the Odra River valley are dominated by mineralogenic deposits. Their sedimentation can be correlated with the accretion of overbank and colluvial sheets in the valley floor. In the light of radiocarbon chronology, a relationship between Neolithic and subsequent phases of settlement in the catchment and the intensive deposition of these sediments cannot be ruled out.

\section{References}

Assmann P., 1934. Zur frage der Terrasenbildung an der oberen Oder. Der Oberschlesier 16: 3-13.
Jahn M. \& Piasecki H., 1952. Zjawiska peryglacjalne na terasach Odry. Czasopismo Geograficzne 21/22: 392-402.

KulczycKa-Leciejewiczowa A., 1993. Osadnictwo neolityczne w Polsce potudniowo-zachodniej. Próba zarysu organizacji przestrzennej. Instytut Archeologii i Etnologii PAN, Wrocław.

MAzUR S., 2006. Geneza i rozwój torfowiska niskiego w Większycach k/Koźla w dolinie górnej Odry. M.Sc. Thesis manuscript WNoZ, Sosnowiec.

Schubert C., 1930. Pollenanalytische Untersuchungen im Wiegschützer Moor. Der Oberschlesier 12: 435-440.

SzczePANKIEWICZ S., 1974. Osady i formy czwartorzędowe Opolszczyzny. In: J. Rutkowski (ed.), Przewodnik XLVI zjazdu Polskiego Towarzystwa Geologicznego, Opole, 12-14 września 1974. Wydawnictwa Geologiczne, Warszawa: 69-89.

ŚLESZYŃSKI P., 2006. Zapis sedymentacyjny i parametry geometryczne paleomeandrów Odry poniżej Koźla jako wskaźnik warunków paleohydraulicznych i środowiskowych w holocenie. M.Sc. Thesis manuscript WNoZ, Sosnowiec.

Trzepla M., 1997. Objaśnienia do szczegótowej mapy geologicznej Polski. PIG, Warszawa.

UrmesstisChBLATt, 1825a. Blatt 3304 Cosel, 1:25 000.

URMESSTISChBLATt, 1825b. Blatt 3253 Gogolin, 1:25 000.

WAGA J.M., 1994. Rzeźba eoliczna na obszarze wschodniej części Niecki Kozielskiej. Scripta Rudensia 2: 3-130.

WALCZAKÓWNa M. \& BARANOWSKA W., 1964. Epigenetyczny przełom Odry pod Krapkowicami. Czasopismo Geograficzne 35: 201-212.

WójCICKI K., 2006. The oxbow sedimentary subenvironment: its value in palaeogeographical studies as illustrated by selected fluvial systems in the Upper Odra catchment, southern Poland. The Holocene 16(4): 589-603. 